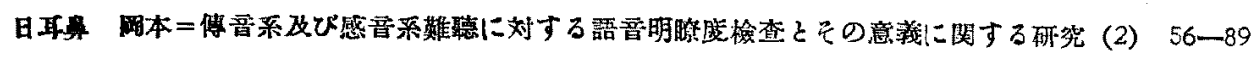

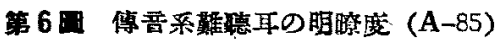

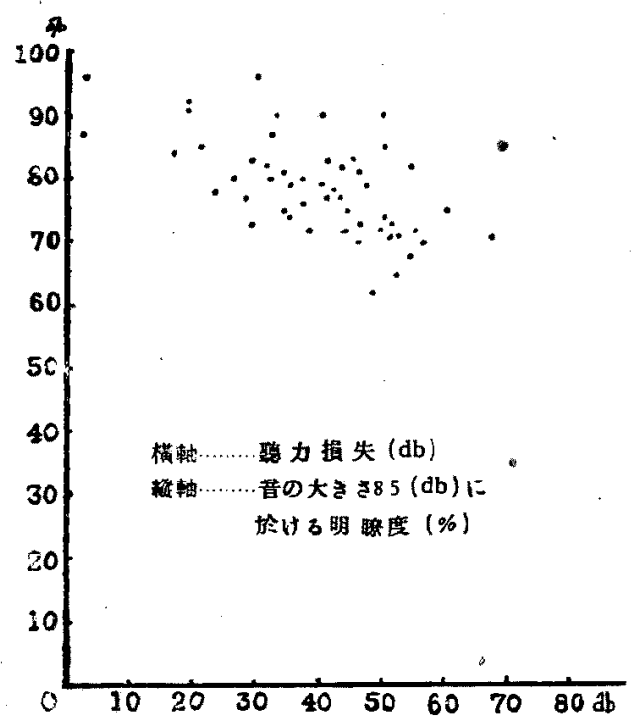

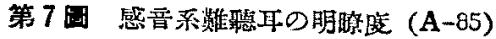

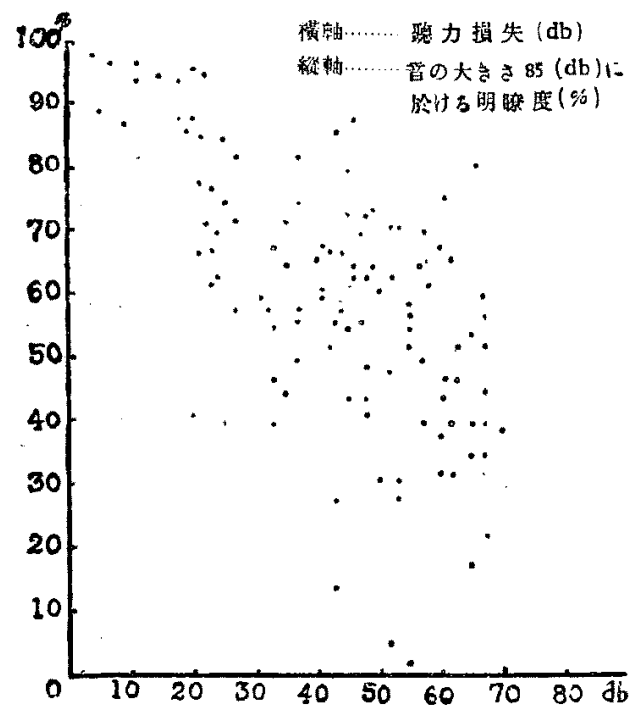

M. OKAMOTO, M.D.: SPEECH RECEPTION TEST OF THE HEARING ACUITY OF THE CONDUCTIVE AND NERVE DEAF

傳音系及ひ感音系難聽に對する語音明瞭度 檢查とその意義に關する研究 (2)

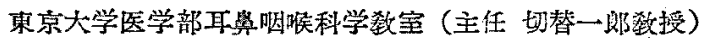

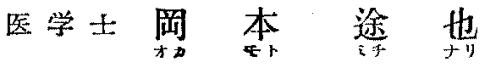

目次

IV 考 按

1 本检查法の吟味

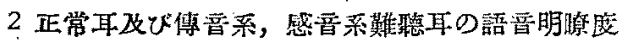
曲楾

3 上述の結果に閉する考按

V 総括並に結論

VI 交湖

\section{IV 考按}

如何なる方法によるとせよ㯖力检查に於て言語㯖

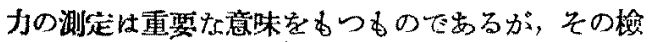
查結果は偏移が大きく，精密を期する事が出來ない ので,これが言語聽力檢查の缺點とされていた。 そ $2-19$
の主要な原因は，检查用棓，检者の警の性質並に章 量が一定さ扎す，他方，被检者の知能侸上る連合作 用，心理狀態等が關倸するからである。

\section{1 本檢查法の吟味}

(1) 試驗音の大きさと模查結果の 偏移との關倸

著者は出來るたシけ上逑の缺點を除く笉，先飞發装

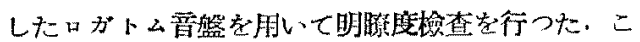
れK上れば正常耳の語音明膫度は第 1 ・第 2 表䏡

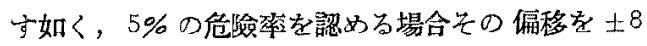
\%以下にすることが出來, 誤差籍園は $15 \%$ 以內と なる. しかる50〜85db とてはその信賴度はさらに 高く，誤差範圍は 10\%以队縮少する. Thurlow 
等\& PB 試驗表 (Phonetically Balanced Word List）暑盤を用いて檢查し， $85 \mathrm{db}$ の曋の大きさに ては正常耳の明瞭度の標集誤差は 7.83\%であるとい つている。この試驗表は著者の用いた語表とや了 翼なり，意義のある一畐節語 (例 bad, speed)を 用いているが，その漂淮誤差は雨試驗とあ注ぶ等し い數值を示している.

㺖端に小さい番 (35db 以下) ヌは大きい吾 (100 db 以上）で检查した場合，その明膫度の偏移仕 35 〜100db の产の大きさで檢查した場合の偏移より あ大きいが，これは被检者の中には小さい吾は聽文 ないすのと早期信謗め，大きい音で怯不快感を減弱 せんとして受話器を正確に耳介及び外耳道に蔆用し

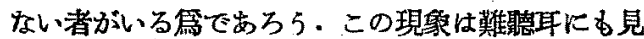

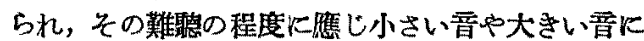
對しては中等度の琝の大きさに對するよりる明膫度 の偏移が大でする。

（2）他側耳索遮西要で遮嫩した場合； 檢查耳に及汸す影照

正常耳の明膫度学測定するにその明膫度は反對側 の耳を 75dbのサイラトロンノイズで遮蔽してい，

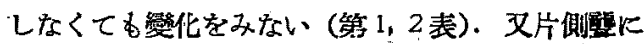
ては健側耳をサイラトロンノイズとて遮蔽すれば患 側耳の明瞭度は測定出來ないが，遮蔽しなければ全

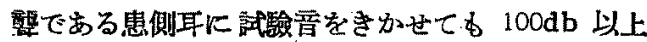

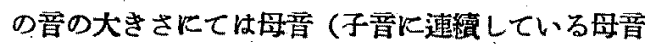

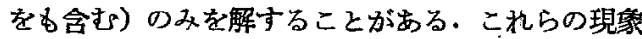
は次の事を示していると考えられる。

a. 反對側耳をサイトロッ, 蔽してる 30〜120db の音の大きざでの明膫度敛亘

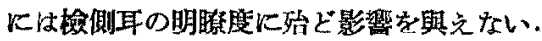

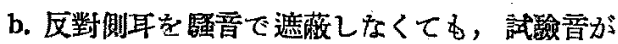
空氣又は骨傳導にて反對側耳火傳言されることは㱠 んどない，多少傳吾されてす母晋を聽取し得ること がある程度にして，明瞭度には大した影響を與えな い.

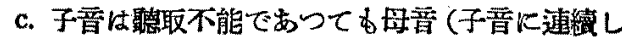
ている母吾をす含む）はきるとり得ることがある。 これは 母吾が子至よりす吾が 5 20db あ大きく (Beasley)，聽取時間も長い篇であろ5。

(3) 反㠅測定による明膫度の偏移
予め 10 組 (20 語)を騂取せしめ，本检查方法を 了解した被檢者飞て，同一音盤により明睹度儉查を 反嘌してす，その成樍の偏移は少く，先に述一た(1) の誤差範園內に含まれる。1日〜6ヶ月を铗て湘定 を反覆してす同稼比膫度の偏移は少である. Thurlow 等忙反潭测定飞上る明暸度の偏稳は 33db の 吾の大きさに゙て $\pm 10 \%$ 以內と云い，Weille 蝴滕 鹿の最高值が $89 \%$ 上り $91 \%$ K上䒜したのみである と云つている.

著者は彼等の方法と異なり無意味な語とよる俭查。 であるから，Thurlow，Weille の行つた有意な語 と上る檢查上りる更仁記憶，連合作用等中楅の作用 による影響は少く，反覆測定を行つてるこれらの作 用の影響による明瞵度の偏移は小であると考え゙られ 尚.

傳晋系片側難聽飞於て夫々別々に雨耳の明嘹度を 测定すれば，各を巽なつた數値を示す。この事蜄は

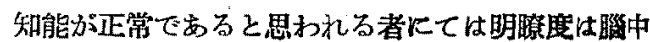
樞に於ける言語の辩别能力によるよりす主として末

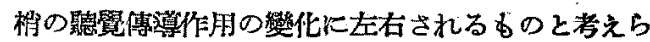
机了。

2 正常耳及び傳槅系，感吾系難璤耳の， 語曋明膫度曲線

（1）正常耳の語晋明膫度曲線

正常耳の語善明勝度曲線を第 3 圖に示寸. 正常耳 の明沓度は音の大きさ $50 \mathrm{db}$ 迄に急速に上昇し，60

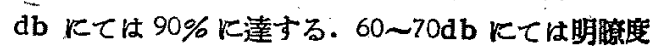
К大した橔化を見ないが，85db 以上の吾の头ささ

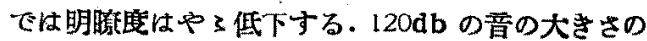

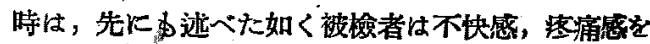

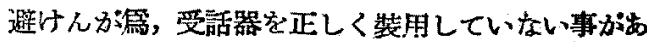
ろので，聽取害が正確に $120 \mathrm{db}$ の霄の大きさであ るとは糍言出來ない，しかし如何なる音の大きさと しろ，明楾度は $100 \%$ Кなり得なからたのは检查用 語及び裝置の不備による晋の歪みの篇であうらが， この曲線㤝 Fletcher, Davis (PB test) の明膫度 曲線七大体一致している。

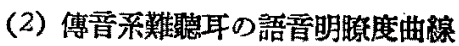

傳曋系難聽の明膫度曲線仙第 4 圖多び第 8 圖に示 す如く，台を大きくして䁛取せしめると明膫度は大 第に上算し，80\%以上Kなる。しかすをの曲線の 


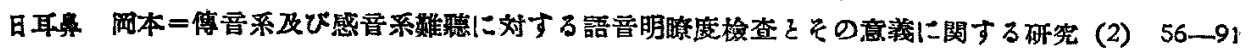

第 8 回 傅晋系難㯖耳の明暸度曲線（第4図の各明暸度曲線の本均值を示す）

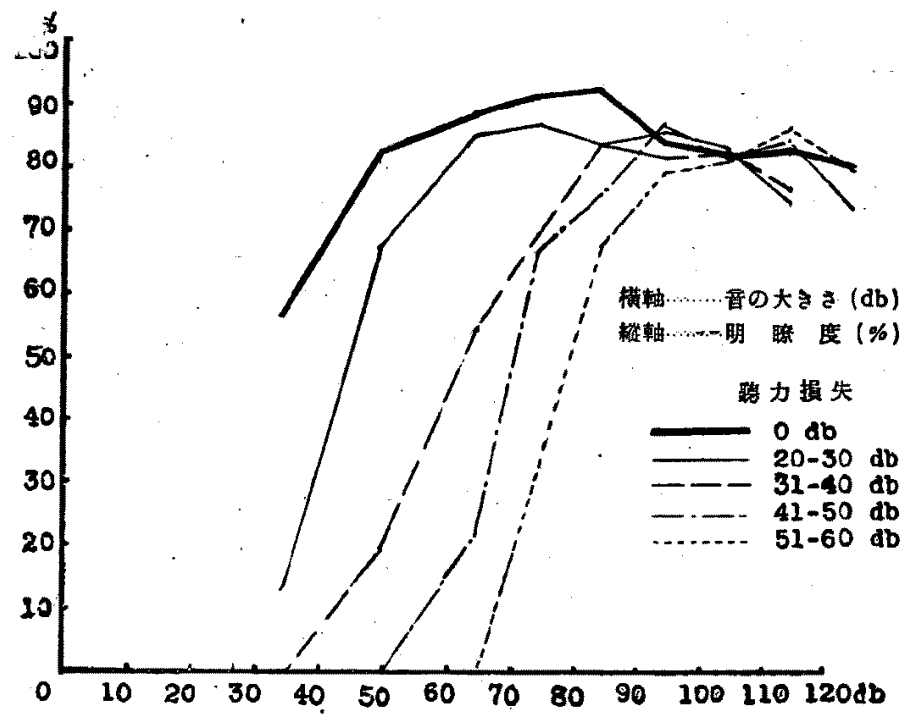

型は曋の大きさの軸に沿つてズレはあるが，大体正 常耳の明暸度曲線之相似の上昇型である. 即ち揌力

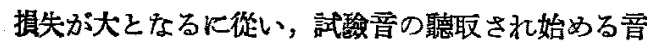
の大きさる大なることを要し，明瞭度曲線の上戒す 各々䥺力損失の度に應して大なる吾の大きさを必要 としている、明膫度が50\%になるには Davis 等は 㮔々の程度の䧼㯖者の純昔㴔力關值より $33 \mathrm{db}$ 大き 以音を要士ると云つているが，著者の檢查結果もは ほこれに等しく，聽力閣値より 20〜30db 大きい音

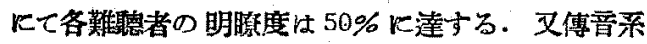
蜼聽の 明膫度はすへて 80\% 以上になるが，それに 恃各々の㯖力閣值上り $50 \mathrm{db}$ 大きい音の大きさが必 要である. Saltzman, Ersner す聽力闌值より 30 〜 50db 大きい㱏にて傳吾系䧼璤者は會話が可能て あると云つている。

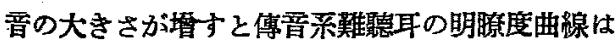
正常耳の明膫使曲楾七合致するか，交齐する・しか し極端に音が大きくならた時，前者の方が後者より 6明暸度がよい例をみるが，これ統計學的仁有意 義とは認め得なかつた。

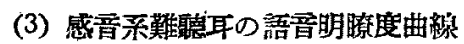

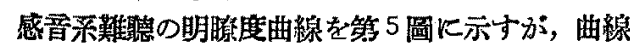
型岋種子雅多で一㧺の關係を認めがたい，音の大き

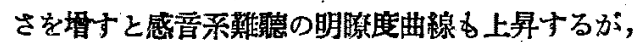

傳夏系難㮩の場合飞予期せられる如くは上昇せす，

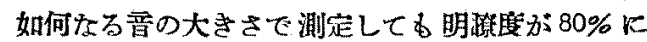
澾しないるのを見る。

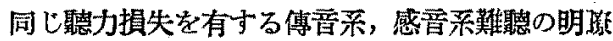
度を比較すると（第 4, 5 周），音の大きさが小さい

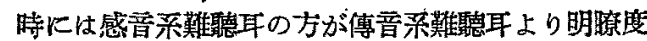
の高い例が多いが，曋の大きさを瞥すと Saltzman， Ersner \&認めているごとく感恿系難聽耳の方が等

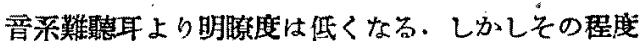
は種々で，殆んぞ傳㡍柔難聽耳の明膫度と同じすの がら非常低いるのまであり，晋の大きさを增すと がつて明睹度の下降士るすのすらむる。

Davis 等は明膫度曲線の上昇する型により 3 型 に分ち，傳音系，感害系及び混合系の難㯖明膫度曲 線としている，そのうっの傅要柔の難聽明腺度曲線

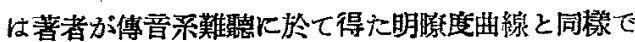

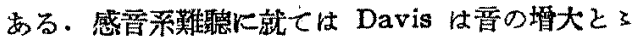
すと眀膫度曲線は上昇はするがその中途より上昇を

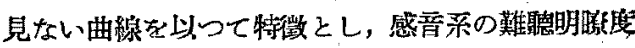

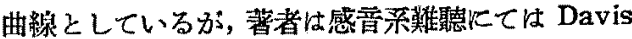
の云万感音系の難聽明膫度曲線型以外飞傳曋系及び

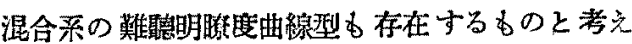
る. 郎ち感吾系難聴は俊されれた部位及びその程度に より䍋々の曲緣型を示すのであろう。 


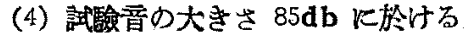
各種䧼㮩耳の明腾度

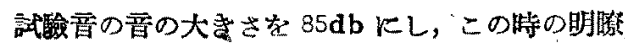

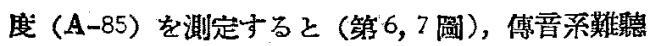

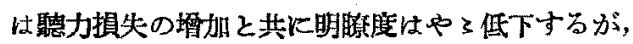

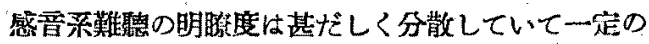
關係を求めることが困難である。兩者の明睠庋を比 較すると，同し㯖力損失を有する難聽でむ感音系蒦

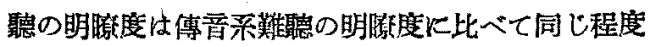
の6のから非裳飞低い6のまである。

\section{3.上述の結果炘關寸当考按}

（1）傳音系蜼聽の言語鳃力

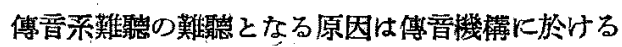

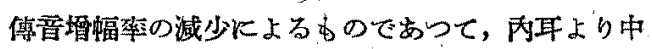

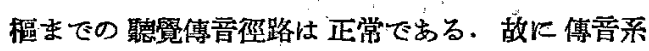

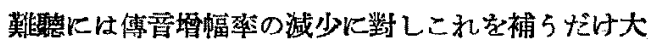
きい言を聞かせれば，正常耳と殆ど同樣に內耳刺 戟さ机昔を感受することが出來る・純昔驄力圖上り 傅要增幅案强失度を推定し $(512,1024,2048$ サ1 クルの愻力損失の平㚬值で表すこととす)，これと 等しく增幅した大きい音を聽取せしされば，難聽耳 わ正常耳と殆ど同样の音安聽取することが出來る。 郎ち著者の檢查結果によれば正常耳及び傅害系難聽 耳は純害聽力の戌值より。50db 大きい吾を聽取せし

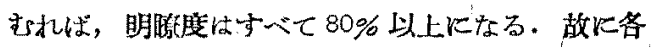

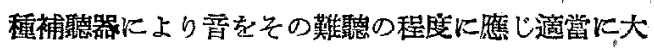

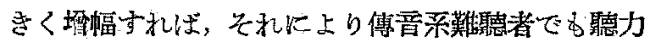
をす分程度墂强し得る。

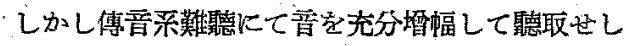

めてす難聽耳の眀蹽度はすへてて正常耳の最大の明晵 度よりや了低い:この理由は著者の測定裝置は 110 $\mathrm{db}$ より大きい沓を歪みなく峧することは困難であ

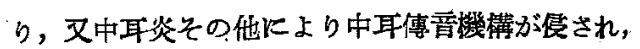
中耳傳音機棈の音響特性か絽化を來しているためた

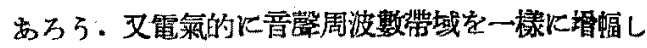

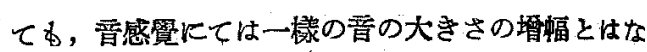
り得ない，即ち語夏飞於ける各フォルマントの太 さと，電氯的熷幅した音のフォルマントの大きさ

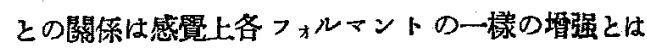
ならないため,これらの至はや々翼なつた吾として 耳感受される。

大きい音の大きさの試驗音で眀眣既を检すると，

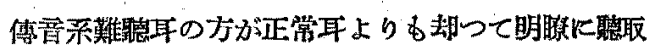

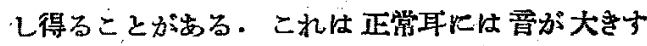
ぎ，その原因は不明ではするか不快感，客痛学感

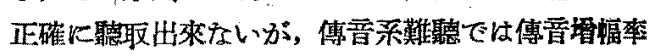
の減少の爲, これらの䦪值に達せず，明睹に㯖取す ることが可能となり得るのであるら.

(2) 感疍系蜼聽の言語聽力

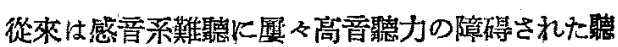
力型があり，そのため感音系難聽は言語聽取が困難 であるっとされてきた。著者の檢查結果より高音障碍 と明睽度との關俰を見れば第9圆の如くなる。郎ち

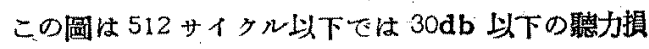

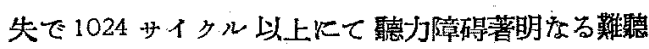

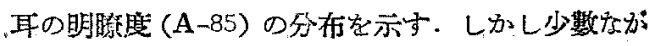

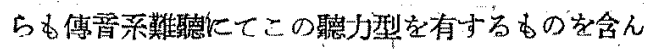
でいる。これによると高晋障碍が著明になると從い

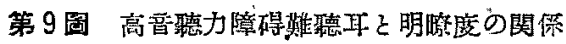

\begin{tabular}{|c|c|c|c|}
\hline $20252048 \sim$ & $0-40 \mathrm{dJ}$ & $41-60 \mathrm{dD}$ & $6106=$ \\
\hline $0-30 \mathrm{db}$ & $\begin{array}{l}91,85,78 \\
71,68,61 \\
-\ldots-41\end{array}$ & $\begin{array}{r}89,85,75 \\
73,71,67 \\
--49,14\end{array}$ & $\begin{array}{l}76,64,63 \\
56,50 \\
--49,45\end{array}$ \\
\hline $3 l-60 a b$ & & $\begin{array}{l}76,72,67 \\
64,62,60 \\
-\end{array}$ & $\begin{array}{l}73,64,59 \\
48,39, \\
-\end{array}$ \\
\hline $61 \mathrm{db}-$ & & & \\
\hline
\end{tabular}

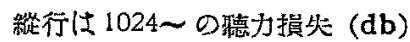

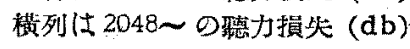

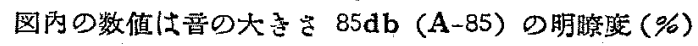




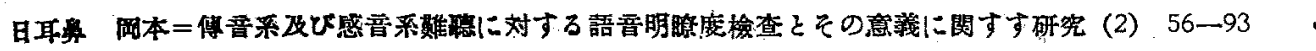

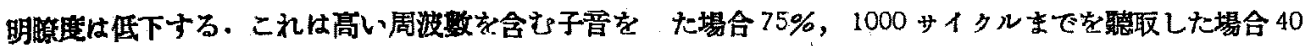

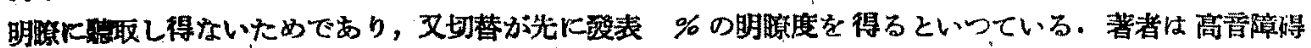

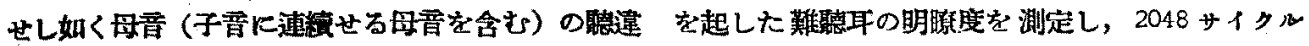

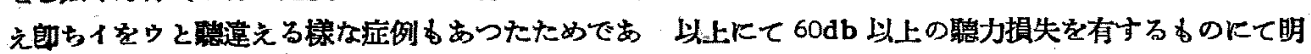

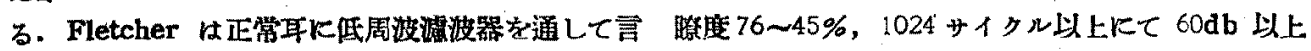

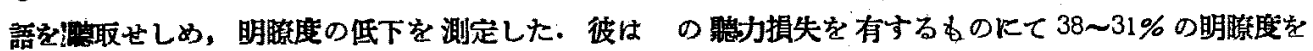

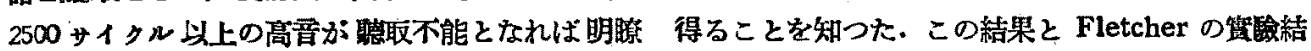

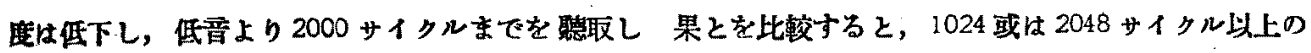

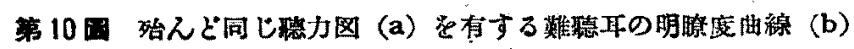

(a) 聴力図

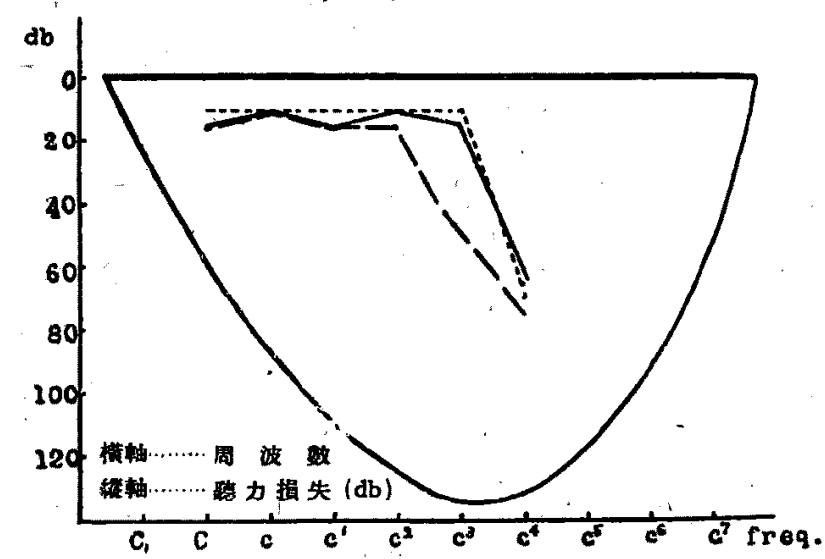

(b) 明瞭度曲楾

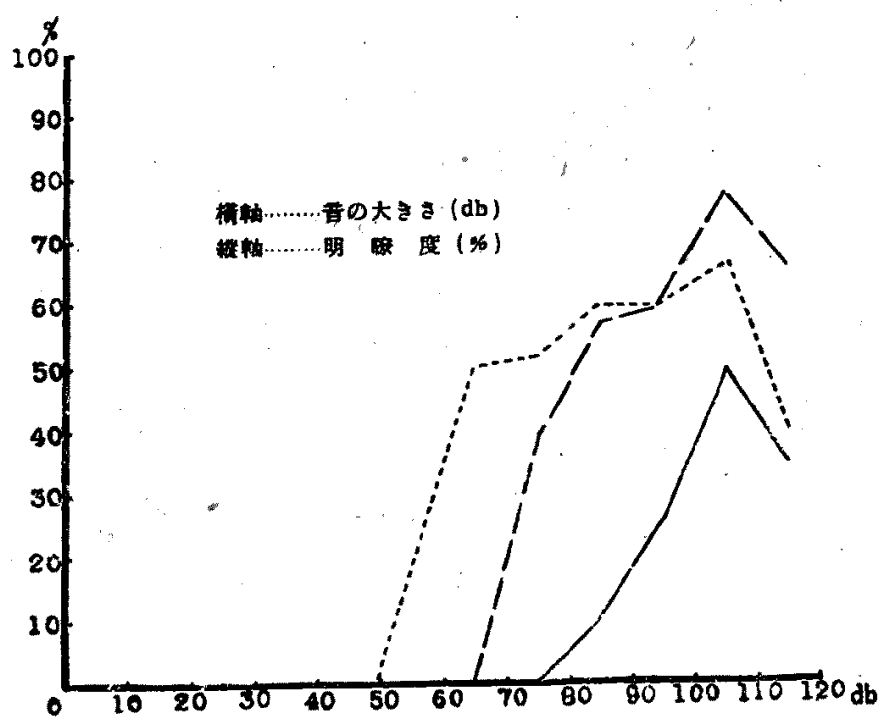




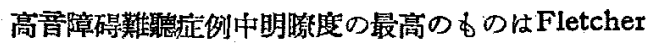
の得た 1000,2000 サイタル以下を聽取し得た正常耳 の明燃度とほご一致与る。

しかし策 9 國にみる如く同し程度の高音障碍の䍡

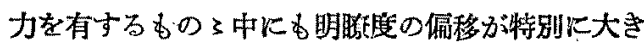
く，著明に低いものがある。郎ち Saltzman, Ersner, Beasley 及び Rosenwasser を報告している

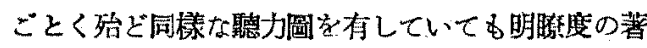

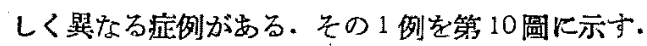
かくの如く純音可聽閥值が㱠んど同程度でる明睹度 が巽なる症例を見るこどは先に述へた Fletcher の望驗結果とは一政しない。

しかしこの異なる明暸嘅の中，最高值は Fletcher の算驗に於てこの難聽と對碓すると考兄られる低周 波濾波器を通して正常耳が聽取した明膫度とほ、゙等

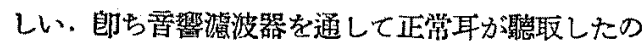
と難聽耳が裸耳火て聽取したのとではその性筫が等 しい場合としからざる場合があると考えられる。か

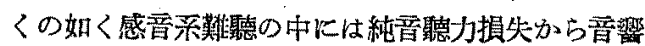
物理學的飞考察して言語聽力の推定出來ない難聽か ある、この原因を Saltzman, Ersner は聽神秝の

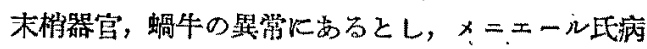

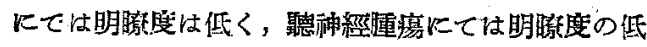

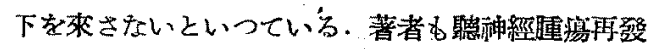

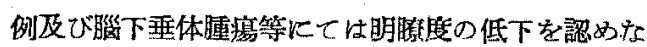

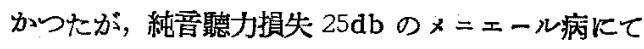
明㬗度(A-85) が 65\% なる例を見ている。

(3) 言語㜇力の意義

上述の諸結果より考えて，㯖能を表現するに當の

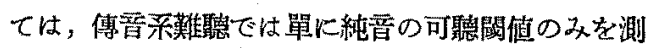
定するナ゙けでとの聽力を吾響物理學的に推測され得

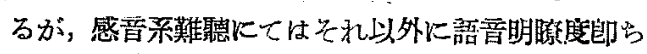
至の高さ，大きさの辫別之の他の綜合されたむのを 湘定し蛤牛或は聴神經の生理學的, 病理學的機能を 考慮する必要がある。

すでに Fowler は感音系蜼聰の中には音の大き

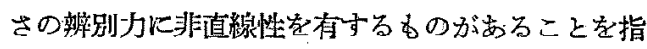

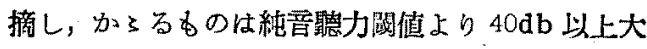
きい音の大きさの言語をきけ将言語はかえつて不眀 眿となるといつている.著者の檢查結果にてす感曋 系難聽にて純曋成值より $40 \mathrm{db}$ 以上大きい吾の大き
さにて明胉度を測定すれば，かえつてそれより小さ

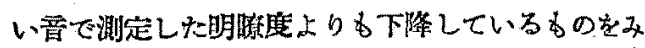

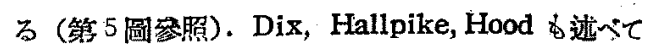
いるごとく音の大きさ炕累加現触が出つてる，了解

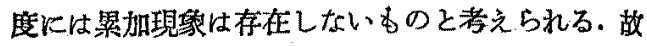
に耳に入つた音が如何に正しく聴覺中楅に感受され たが測定する必要がする。このことをSaltzman, Ersner は正確傳曋因子 (transmission fidelity factor) といつているが，これは純音聽力と言語聰

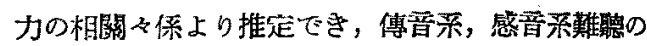
鑑別及び感昔系難复の診断上重要な要素となる。

又明脱度檢查は純音による諸聽力檢查と相俟つて 䧼聽耳治療の場合比微細な聽力䍃動をる見出し得る 利點があり，ことに可㯖閥值より大きい音に對する 聽力の變動を推察し得る。骨導㯖力檢查々共飞他の

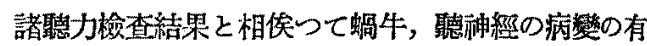
無を推定し得るが故に迷路開空術の適應決定等に役

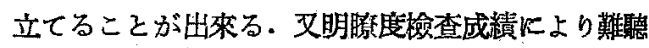
者の最す望む言語疆力即ち日常生活に於ける活動能 力を推定し，かくて補隐器により䧼聽を補い得る程 度をす知ることが出柬る。

\section{V 總括並に結論}

1）著者の製作せるロガトム音盤を使用して正常 耳及び各種難聽耳の語曋明眣度を测定した.

2）語吾明膫选檢查は從來行われてきた言語によ る聽力㮝查に比し高股の信賴性を有し，その信賴限 界は $\pm 8 \%$ 以下である。

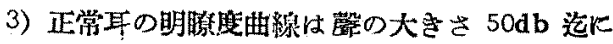
急速に上年し，65db Kて $90 \%$ 飞達する。 $85 \mathrm{db}$ 上飞ては明既度はや了低下する。

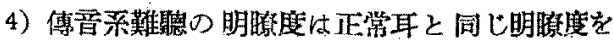
得るにはその純音疆力損失の度化鷹し大きい音の大 きさを要し，その曲線は正党耳の曲線と㱠ど同型を

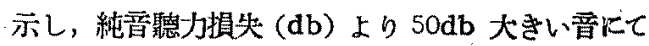
明睦度は $80 \%$ 以上飞なる。

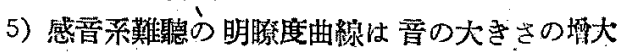
と共比上算するが，一定の型を定めがたく，又明㹉 度は $80 \%$ 以上飞溄しないすのがある。

6)同程度の純要聽力損失を有す尚傳吾系，感晋

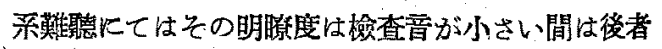

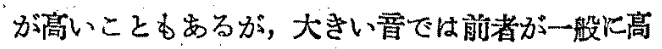




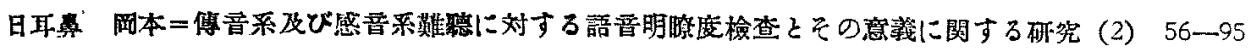

6.

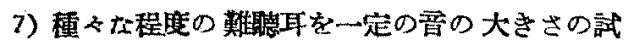

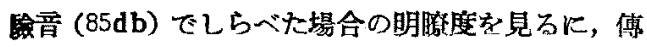
吾系蜼聽では㯖力損失と明眼度との間に一定の關係

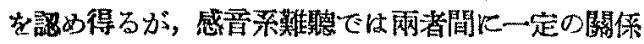
圭敖め難い。

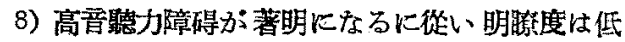

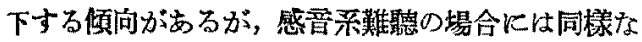

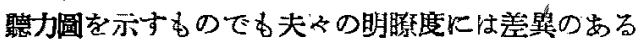
ことがある。

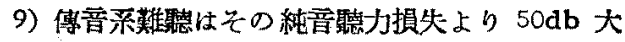
きい寒を聽取すれいば，㱠ど正常耳と同し聽力を得 b.

10）感音禾難聽はその純音聽力損失と言語聽力損 失との間に一定の關係を認め難いものが多い。

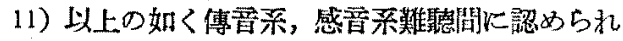

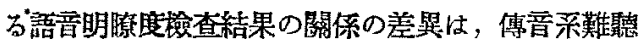
の㣰力その6のは主音留物理學的要素で說明出來

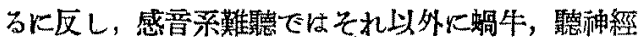
の理々なる生理學的, 病理學的要素の介入してくる ため生ずるのであろち。

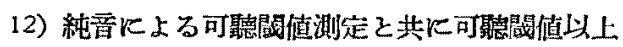
の台の大いさで語豆明睹度檢查を行うことにより，

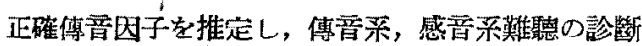
に役立てることが出來る。

\section{V 文献}

1) Davis, H.: Hearing and deafness. New York. 1947. 2) Fletcher, H.: Demonstration of the principles of talking and hearing with applications to radio. Ann. of Otol, etc. 36 : 1, $1927 . \quad 3)$ Fletcher, H.: Speech and hearing. Seventh Printing. New York, 1948.

Fowler, E.P.: The use of threshold and louder sounds in clinical diagnosis and the prescribing of hearing aids. New methods for acuratoly determining the threshold for bone conduction and for measuring tinnitus and its effects on obstractive and neural deafness. Laryngoscope $48: 572,1938$. 5) Fowler, $E$. P.: Medicine of the ear. New York, 1948. 6) Harris, J.D.: Free voice and pure tone $2-25$ audiometer for routine testing of auditory acuity. Arch. of Otolaryng. 44; 1946.

Harris, J.D.: Some suggestions for speech reception testing. Arch. Otolaryng. 50:388, 1949. 8) Harris, J.D., Haines, H.L., Myers, C.K.: Loudness perception for pure tones and for speech. Arch. of Otolaryng. 55: 107. 1952. 9) Hughson, W, Thompsom, E.* Correlation of hearing acuity for speech with direct frequency audiograms. Arch. of Otolaryng. 36:526, 1942. 10) Huizing, H.C., Reyntjes, J.A.: Recruitment and speech discrimination loss. Laryngoscope 67:521, 1952. 11) Rosenwasser, H.: Determining factors in compositing and analyzing speech test. Laryngoscope $60: 658,1950$. 12) Satlzman, $M$. .: Speech hearing in Otosclerosis. Arch, of Otolaryng. $46: 753,1947 . \quad$ 13) Saltzman, $M$., Ersner, M.S.: Psycho-Physiology of speech hearing. Arch. of Otolaryng. 53: 1951. 14) Silverman, S.R.: Use of speech tests for evaluation of clinical procedures. Arch. of Otolaryng. $51: 787,1950$.

15) Silverman, S.R., Thurlow, W.R., Walsh, T.E., Davis, H.: Improvement in the social adequacy of hearing following the fenestration operation.

Laryngoscope 58:607, 1948, 16) Steinberg, I.C., Gardner, M.B.: The dependence of hearing impairment on sound intensity $\mathrm{J}$. Acoust. Soc. Amer. 9: 11, 1937.

17) Stevens, S.S., Davis, H.: Hearing. 1938. 18) Thurlow, W.R., Davis, H., Walsh, T.E., Eldert, E.. A third statistical study of auditory tests in relation to the fenestration operation. Laryngoscope 61: 124, 1951 .

19) Weille, F.L.: Speech audiometry in practical use. Arch. of Otolaryng. 55:456, 1952. 20) 河用政一：余

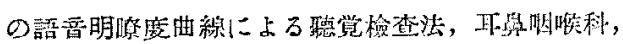

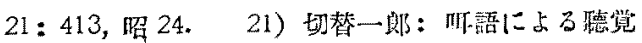
检查について，總会医学， $5: 4 ，$ 炤 $23.22 ）$ 切替

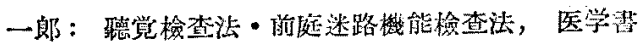




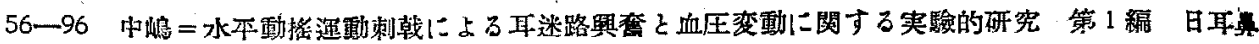

院，1951. 23) 切替一郎，岡本途也：電氮補㯖 器の適應に就いて, 日昔掏会誌, $7: 63 ; 1951$.

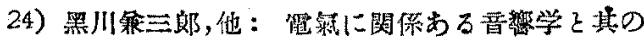

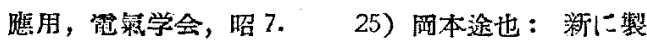

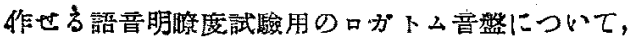

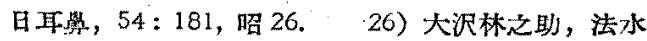

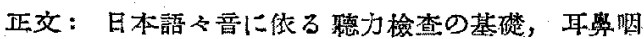

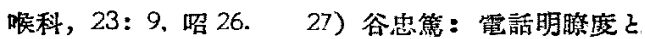

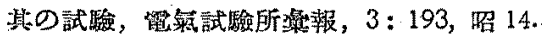

（本稿は炤和 26 年 5 月日本耳费咽喉科学会第
52 回総会にてその一部を笔表した。）

（本研究には昭和 24 年度文部省科学試驗研究

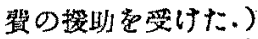

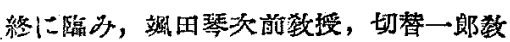
授の御指端之校閱を感謝する。

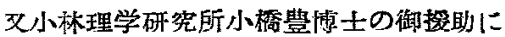

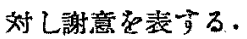

T. NAKASHIMA, M.D.: EXPERIMENTAL STUDIES ON LABYRINTH STIMULATION AND BLOOD PRESSURE ALTERATION INDUCED BY HORIZONTAL SWINGING MOVEMENT

水平動搂運動刺战による耳迷路興奮 血壓變動に關する實驗的研究

第 1 編 水本動搖運動刺戟に對す万耳迷路と 血壓の態度に就て

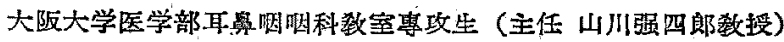

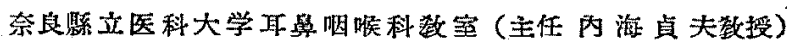

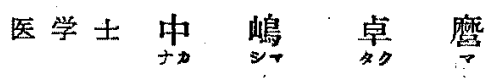

\section{全蹁目次}

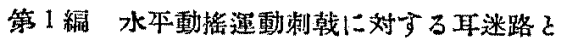
血圧の態度に就て

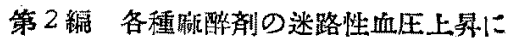

改ぼ影曾に就て

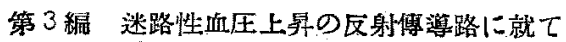

\section{本編目次}

I）緒言

II）実殹装置及び実驗力法

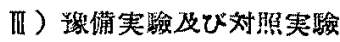

IV) 実驗或續

V) 粉括及び洘按

V) 結 論

\section{I)}

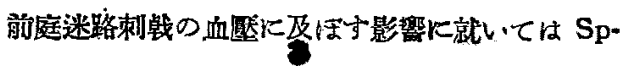

iegel u. Démétriades (1922) 1).赛险發表以來多

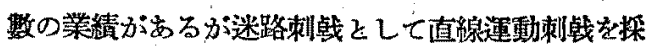
用したすのは比較的稀でする。唯值線運動の中の开

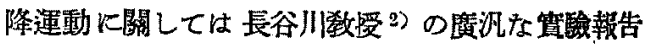

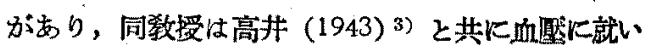
てる明かにされて居る。著者は動播病研究の一端と して吾人の最す多く遭造する水平陲滛運動を採り上

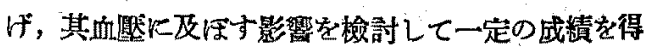

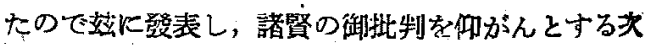
第で各。

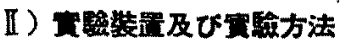

実驗裝置：自家考察の水平動搖運動装置（動摇距

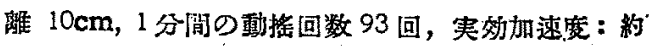
$280 \mathrm{~m} / \mathrm{sec}^{2}$ ，実勃㧈速度変化：約 $2637 \mathrm{~cm} / \mathrm{sec}^{\mathrm{B}}$ ) 如使 用した。 